University of Chicago Law School

Chicago Unbound

Public Law and Legal Theory Working Papers

Working Papers

2010

\title{
The Demarcation Problem in Jurisprudence: A New Case for Skepticism
}

Brian Leiter

Follow this and additional works at: https://chicagounbound.uchicago.edu/public_law_and_legal_theory

Part of the Law Commons

Chicago Unbound includes both works in progress and final versions of articles. Please be aware that a more recent version of this article may be available on Chicago Unbound, SSRN or elsewhere.

\section{Recommended Citation}

Brian Leiter, "The Demarcation Problem in Jurisprudence: A New Case for Skepticism" (University of Chicago Public Law \& Legal Theory Working Paper No. 319, 2010).

This Working Paper is brought to you for free and open access by the Working Papers at Chicago Unbound. It has been accepted for inclusion in Public Law and Legal Theory Working Papers by an authorized administrator of Chicago Unbound. For more information, please contact unbound@law.uchicago.edu. 


\title{
THE DEMARCATION PROBLEM IN JURISPRUDENCE: A NEW CASE FOR SKEPTICISM
}

\author{
Brian Leiter* \\ bleiter@uchicago.edu \\ Draft of May 2, 2010 \\ Please do not cite or quote without permission. \\ To be presented at the conference on "Neutrality and Theory of Law" at the University of \\ Girona, Spain, May 212010
}

For more than two hundred years, legal philosophers have been preoccupied with specifying the differences between two systems of normative guidance that are omnipresent in all modern human societies: law and morality. In the last hundred years, what I will call the "Demarcation Problem"- the problem of how to distinguish these two normative systems - has been the dominant problem in jurisprudence and legal positivism has offered the most important solution. Positivists such as Kelsen, Hart, and Raz claim that the legal validity of a norm can not depend on its being morally valid, either in all or at least some possible legal systems (the range of the scope operator here marks the distinction between "Hard" and "Soft" versions of positivism).

Kelsen tells us on the first page of the Pure Theory that the theory "attempts to answer the question what and how the law is, not how it ought to be" 1 and the second chapter on "Law and Morals" sets out to establish that the "science of law"- the science of the legal validity of norms - is not to be confused with "ethics," the science of the social norms denominated "moral" (59). "[L]aw and morals" must be "recognized as different kinds of normative systems" (62), Kelsen says, a difference he locates in the fact

\footnotetext{
${ }^{*}$ This paper owes its existence to a conversation with Larry Laudan.

${ }^{1}$ Hans Kelsen, Pure Theory of Law, trans. Max Knight (Berkeley: University of California Press, 1967), p. 1. Further citations are included by page number in the body of the text.
} 
that law involves "a socially organized coercive" sanction, while morals lacks such sanctions, substituting "merely the approval of the norm-conforming and the disapproval of the norm-opposing behavior" (62).

The first sentence of The Concept of Law states Hart's aim "to further the understanding of law, coercion, and morality as different but related phenomena" (vi). He famously identifies as one of the three main issues driving jurisprudential inquiry the question, "How does legal obligation differ from, and how is it related to, moral obligation?" (13). That issue looms so large because "law and morals share a vocabulary so that there are both legal and moral obligations, duties, and rights" and "all legal municipal legal systems reproduce the substance of certain fundamental moral requirements" (7). This, of course, leads positivism's most important competitor, natural law theory, to claim "that law is best understood as a 'branch' of morality or justice." Positivists, of course, deny this. Finally, and as is well-known, Hart devotes an entire chapter of The Concept of Law to the relationship between "Law and Morals," noting that positivists deny that "the criteria of legal validity of particular laws used in a legal system must include, tacitly if not explicitly, a reference to morality or justice" (185) and that, in consequence, "it is in no sense a necessary truth that laws reproduce or satisfy certain demands of morality, though in fact they have often done so" (185-186).

Raz, similarly, devotes fully half of his classic collection of essays, The Authority of Law, to "criticiz[ing] various attempts to establish a conceptual connection between law and morality" (x) and the seminal chapter on "Legal Positivism and the Sources of Law" makes clear that the identification of law "is a matter of social fact" that is independent of its "moral merit" (37). 
If it is familiar and uncontroversial that the Demarcation Problem has been central to legal philosophy, it perhaps requires more emphasis what kind of answer to the Demaracation Problem jurisprudents have demanded. Hart himself says we want to understand "the nature (or the essence) of law" (6). But what is it to understand the nature or the essence of law? Julie Dickson, following Raz, says that,

A successful theory of law...is a theory which consists of propositions about the law which (1) are necessarily true, and (2) adequately explain the nature of law.... am using "the nature of law" to refer to those essential properties which a given set of phenomena must exhibit in order to be law. ${ }^{2}$

She is echoed more recently by Scott Shapiro, who says that in inquiring into "the fundamental nature of law" we want to "supply the set of properties that make (possible or actual) instances of [law] the things that they are"3 and offers the example of water being H2O: "Being $\mathrm{H} 2 \mathrm{O}$ is what makes water water. With respect to law, accordingly, to answer the question 'What is law?' on this interpretation is to discover what makes all and only instances of law instances of law and not something else."4 ${ }^{\prime \prime}$ addition, says Shapiro (here again echoing Dickson who is following Raz), "to discover the law's

\footnotetext{
2Julie Dickson, Evaluation and Legal Theory (Oxford: Hart Publishing, 2001), p. 17. Dickson faithfully follows Raz's lead here, though he has not always been so immodest. Thus, in the earlier essay "Legal Positivism and the Sources of Law," reprinted in his The Authority of Law, $2^{\text {nd }}$ ed. (Oxford: Oxford University Press, 2009), Raz notes that it is no part of the argument for the Sources Thesis "that a similar conception of legal systems is to be found in all cultures and in all periods." $I d$. at 50 . That is only one kind of theoretical modesty, for one might still think that it is possible to state necessary truths that explain the essential nature of a culturally and temporally bounded human practice; as noted in the text, our experience in the philosophy of science in the $20^{\text {th }}$-century invites skepticism.

${ }^{3}$ Scott J. Shapiro, Legality (Cambridge, Mass.: Harvard University Press, 2010), [sec. 3 of Ch. 1].

${ }^{4}$ Id.
} 
nature" is also "to discover its necessary properties, i.e., those properties that law could not fail to have."5

Legal philosophy has, unsurprisingly, always been hostage to its philosophical climate-jurisprudents are rarely, if ever, innovators in philosophy. They, instead, are the jurisprudential Owls of Minerva, bringing considered philosophical opinion in its maturity (sometimes, alas, on its death bed) to bear on theoretical questions that arise distinctively in the legal realm. Thus, Kelsen's jurisprudence bears the stamp of NeoKantianism and the moral anti-realism common among logical positivists, while Hart's jurisprudence reflects the methodological influence of ordinary language philosophy and the substantive influence of post-World War II Oxford-style noncognitivism. Kelsen and Hart had the correct meta-ethical views, but did not, perhaps, fully appreciate their import with respect to their central jurisprudential concerns. What is particularly striking is that, even at the dawn of the $21^{\text {st }}$-century, legal philosophers set conditions for a successful analysis of the Demarcation Problem - to identify the "necessary" and "essential" properties of law that distinguish it from morality--that would strike most philosophers in other fields, even thirty years ago, as wholly incredible, even ludicrous. The persistence of the Demarcation Problem means the jurisprudential Owl of Minerva has not yet taken flight. I hope here to set this venerable philosophical bird on her path and to lay the Demarcation Problem to rest.

The concept of law is an "artifact concept," that is, a concept that picks out a phenomenon that owes its existence to human activities - it is, that is, an "artifact" of those activities. Even John Finnis, our leading natural law theorist, does not deny this

\footnotetext{
${ }^{5}$ [next page in MS]
} 
point. $^{6}$ I certainly do not understand Kelsen, Hart, Raz, Dickson, or Shapiro to deny this claim. Those who might want to deny that law is an artifact concept are not my concern here; the extravagance of their metaphysical commitments would be subjects for psychological, not philosophical investigation.

Artifact concepts, even simple ones like "chair," are notoriously resistant to analyses in terms of their essential attributes, precisely because they are hostage to human ends and purposes, and thus can not be individuated by their natural properties - unlike say natural phenomena like "water," which just is $\mathrm{H}_{2} 0$. Chairs can be made of stone or wood or metal. Their apparent function—providing support for those who sit—can be discharged by boxes, tortoises, car seats, and steps. Moreover, some chairs have as their actual function ornamental decoration, not sitting; some serve primarily as shelves for stacking papers or books. Some chairs have arm rests, some do not; some have back rests, some do not. Because human ends and purposes shift, the concept of a "chair" has no essential attributes.

Now the question of whether an artifact concept has an extension that can be picked out in terms of necessary and essential properties is not one unfamiliar to twentieth-century philosophy: far from it. Karl Popper, Rudolf Carnap, and Carl Hempel, to name three luminaries of $20^{\text {th }}$-century philosophy, were interested in a version of the Demarcation Problem - not how to demarcate law from morality, to be sure, but how to demarcate epistemically reliable forms of inquiry from epistemically unreliable ones, that is, how to demarcate science from pseudo-science or nonsense. Like the legal philosophers, they sought to identify the essential properties of a human artifact (namely,

\footnotetext{
${ }^{6}$ [add cites and short discussion]
} 
science). They failed, and spectacularly so. Perhaps there is a lesson for legal philosophers in this story.

In philosophy of science, the Demarcation Problem was the problem of figuring out which kinds of human inquiry were epistemically special, that is, which had epistemic properties or characteristics that warranted the inference that the conclusions of such inquiry were likely to be true. Those epistemically special forms of inquiry were to be deemed scientific, and so deserving of credence, while all others were not. Permit me to quote from Larry Laudan's seminal treatment of the rise and fall of the Demarcation Problem, ${ }^{7}$ which he characterizes as follows:

[W]e expect a demarcation criterion to identify the epistemic or methodological features which mark off scientific beliefs from unscientific ones. We want to know what, if anything, is special about the knowledge claims and the modes of inquiry of the sciences...[A]ny philosophically interesting demarcative device must distinguish scientific and non-scientific matters in a way which exhibits a surer epistemic warrant or evidential ground for science than non-science. If it should happen that there is no such warrant, then the demarcation between science and non-science would turn out to be of little or no philosophic significance. (Laudan, p. 118)

\footnotetext{
${ }^{7}$ Larry Laudan, "The Demise of the Demarcation Problem," in R.S. Cohen \& L. Laudan (eds.), Physics, Philosophy and Psychoanalysis (Dordrecht: D. Reidel, 1983). Cited hereafter by page number in the text.
} 
Attempts to solve the scientific Demarcation Problem were, in turn, precisely efforts to specify the "conditions which are both necessary and sufficient" for some form of inquiry to be scientific (Laudan, p. 119).

The history of the search for such a criterion is quite a long one, going back to antiquity (though the artifact concept Aristotle wanted to understand is different than ours, not surprisingly) (Laudan, pp. 112-113). In the $19^{\text {th }}$-century, there were attempts to specify the distinctive "method" of scientific inquiry (Laudan, pp. 115-117), but the solutions to the scientific Demarcation Problem most familiar to us now were those associated with the Logical Positivists and Karl Popper. "Verificationist" theories held that scientific propositions were genuinely meaningful, that is, empirically verifiable. These theories, however, ran into trouble because, on the one hand, as Laudan observes, "many statements in the sciences [are] not open to exhaustive verification (e.g., all universal laws)" (p. 120), while many false statements - like "the Earth is flat"-are verifiable (though false!) since "we can specify a class of possible observations which would verify" the statement (p. 121). Popper's alternative, eschewing verification for falsifiability, ran into different problems: it could not explain the scientific status of most “singular existential statement[s]" (p. 121) (e.g., "there exists a Black Hole") and it deems "scientific" (and, ergo, epistemically reliable) "every crank claim which makes ascertainably false assertions" (p. 121). ${ }^{8}$

As Laudan observes, we can not "prove that there is no conceivable philosophical reconstruction of our intuitive distinction between the scientific and the non-scientific" (or we might add, between the "legal" and the "moral") (p. 124). But we can conclude,

\footnotetext{
${ }^{8}$ [other issues: Feyerabend on the persistence of falsified theories in the natural science; Duhem-Quine undetermination problem - Laudan rejects this, however]
} 
as Laudan does, that "none of the criteria which have been offered thus far promises to explicate the distinction" (p. 124). We should, therefore, ask why solving the

Demarcation Problem matters? For what philosophical or practical purposes do we need a solution to the Demarcation Problem?

In the case of science, the solution mattered for explicitly practical reasons. As Laudan remarks, "demarcation criteria are typically used as machines du guerre in a polemical battle between rival camps" (p. 119). So, for example, "Popper was out to 'get' Marx and Freud" ( $p$ 119) by showing that their theories were not falsifiable. It is now notorious that Popper had no grasp of either Marx's or Freud's views, ${ }^{9}$ but that is not a dispute we need to resolve here. What matters, as Laudan notes, is that, the labeling of a certain activity as 'scientific' or 'unscientific' has social and political ramifications which go well beyond the taxonomic task of sorting beliefs into two piles....Precisely because a demarcation criterion will serve as a rationale for taking a number of practical actions which may well have far-reaching moral, social and economic consequences, it would be wise to insist that the arguments in favor of any demarcation criterion we intend to take seriously should be especially compelling. (120) In other words, the Demarcation Problem was thought to matter because knowledge matters, because what we know affects what we think ought to be done. As Laudan remarks, "It remains as important as it ever was to ask questions like: When is a claim well confirmed? What can we regard a theory as well tested? What characterizes cognitive progress?" (124). What the failure in philosophy of science to solve the Demarcation Problem shows is that we can not take a shortcut to answers these questions

\footnotetext{
${ }^{9}$ See generally, Brian Leiter, "The Hermeneutics of Suspicion: Recovering Marx, Nietzsche, and Freud," in B. Leiter (ed.), The Future for Philosophy (Oxford: Oxford University Press, 2004).
} 
by simply dividing forms of inquiry into the "scientific" and "non-scientific" based on some necessary and essential properties distinguishing the two forms of inquiry.

So what then about the Demarcation Problem in jurisprudence? I do not need to rehearse for this audience the doubts about the positivist analysis of law, the most powerful and successful analysis of law we have. Many of these doubts may be, as I am inclined to think, misguided, yet who can deny that there are genuinely hard cases for the positivist to explain? Hart says that the "necessary and sufficient conditions" for a legal system require that citizens generally obey the valid primary rules and that the officials of the system accept the secondary rules of the system from an "internal point of view," that is, they view them as imposing obligations upon them. Can there not then be a legal system in which the officials are motivated by merely self-interested concerns, e.g., they enforce the secondary rules because it advances their professional career or spares them from political retribution? Can the idea of a rule of recognition really account for the reasoning of common-law courts interpreting precedents? Hart says the "rule of recognition" is merely a social rule, so its content is fixed by whatever the practice of officials in a particular legal system happens to be. Raz says the practice can not include appeal to moral criteria of legal validity consistent with the law's claim to authority. Shapiro says it can not include such appeals consistent with the law's claim to guide conduct. Waluchow argues the law's claim to authority is compatible with an official practice of employing moral criteria of legal validity if authoritative directives are merely weighty, rather than exclusionary, reasons for action. And so on.

If, in the history of philosophy, there is not a single successful analysis of the "necessary" or "essential" properties of a human artifact, why should we think law will 
be different? If hundreds, perhaps thousands, of philosophers in the last century--both the innovators like Carnap and Popper, and the legions of less well-known philosophical laborers - could not specify the essential and necessary features of science, perhaps the most important and transformative human artifact of recorded history, should we really hold out hope that an analysis of law will yield "necessary" and "essential" criteria?

A skeptical induction over past failure is not a conclusive refutation, just as the failure to solve the Demarcation Problem in philosophy of science does not prove that there is no account of the essential and necessary properties of an inquiry that is scientific. But, rather than belabor the no-doubt familiar disputes about the Demarcation Problem in jurisprudence, let us follow Laudan's lead and ask a different question: namely, why does solving this problem matter?

In surveying the writings of the great writers on the Demarcation Problem in jurisprudence - I here mean Kelsen, Hart, and Raz - it seems that two practical concerns explain the importance for these writers, and those who follow them, of demarcating legal from moral norms ${ }^{10}$ :

(1) First, the fact that a norm is legally valid does not mean it is morally obligatory.

(2) Second, the fact that a decision by a legal official would be morally attractive does not mean it is legally obligatory.

In other words, legal positivists - those who have insisted that the Demarcation Problem can be solved — are keen to emphasize that legality does not entail morality and, conversely, that morality does not entail legality. You will notice, of course, that the

\footnotetext{
${ }^{10}$ I do not mean to deny that these writers also have a purely theoretical concern, i.e., figuring out what they take to be true of the concept of law. But since there is no reason to think this is a sensible theoretical project-unless ethnographically and temporally bounded in ways that are not obvious congenial to their original ambitions--it is important to focus on its import for practical reasoning.
} 
need to draw this distinction, to solve the Demarcation Problem, turns on the assumption that the moral validity of a norm entails a practical consequence, i.e., it entails acting in accordance with the norm. If we grant that assumption, then confusing law and morality has serious practical consequences indeed: it means that if the legal validity of a norm is equivalent to its moral validity, then every law ought to be obeyed. And, conversely, it means that if a norm is morally valid, then a legal actor ought to apply it.

The Demarcation Problem in philosophy of science was meant to solve a normative problem about theoretical rationality, about what we ought to believe. But, as Laudan correctly observed, its solution had consequences for practical reason, for what ought to be done, and it was these that motivated the ultimately futile search for a theoretical short-cut. The Demarcation Problem in jurisprudence also purports to resolve a theoretical dilemma: what to believe about the nature of law. But the connection of an answer to this question to matters of practical import is even more apparent. We can perhaps defuse the Demarcation Problem in jurisprudence if we tackle its underlying assumption: namely, that the moral validity of a norm is overriding in practical reasoning.

Suppose it were agreed that the moral validity of a norm was not overriding in practical reasoning. Suppose morally valid norms merely give defeasible (even easily defeasible) reasons for acting, just like legally valid norms and norms of instrumental rationality. That a norm was legally valid might, in some cases, also mean it is morally valid, but what if that did not change one's reasoning about what ought to be done? That a norm was morally valid might be an interesting fact for a judge to note, but it would not 
require from the judge one decision rather than another. In such a world, would solving the Demarcation Problem in jurisprudence matter? It is hard to see why.

Kelsen and Hart, as everyone knows, were both metaphysical anti-realists about moral norms: that is, they denied that such norms had any objective existence, they denied that the best metaphysical account of what the world contains would include facts about what is morally right and wrong. This might suggest that the normativity of morals — its ability to give people reasons to act — should be understood in exclusively psychological terms, i.e., as a fact about what particular people believe and feel when they learn that, "It is morally wrong to do X" or "It is morally right to Y." Hart, in fact, accepted something like this view, since, unlike Kelsen, his was an "impure" theory of law, in which anti-realism about norms was conjoined with non-cognitivism about the semantics of normative judgment: to judge that doing $\mathrm{X}$ is morally (or legally) wrong is just to express a certain kind of attitude or feeling, presumably one tiedpsychologically_to motivation and action. ${ }^{11}$ Insofar as Hart believed, quite reasonably, that people thought moral rightness demanded action, he had good reason to worry about the Demarcation Problem. The "purity" of Kelsen's theory-his reluctance to assimilate the normativity of law to psycho-social facts about behavior and attitudes - might seem to block the naturalization of the problem suggested by Hart's approach. I am afraid I am with Hume, Nietzsche, and Hart in being skeptical that any sense can be given to the NeoKantian idea of the grounds of intelligibility of the application of norms apart from a psychological one. I am also fairly confident (contra Quine and his retrograde

\footnotetext{
${ }^{11}$ See, e.g., Kevin Toh, "Hart's Expressivism and his Benthamite Project," Legal Theory __ (2005): __- _. See also, Kevin Toh, "Objectivity and the Plural Acceptance of Norms," in Oxford Studies in the Philosophy of Law, Volume 1, ed. L. Green \& B. Leiter (Oxford: Oxford University Press, 2011).
} 
psychological behaviorism) that our best theory of the world will quantify over

psychological states and persons, but it will not quantify over moral norms, ${ }^{12}$ and so we need to approach the Demarcation Problem in that spirit.

If we understand the idea of the morally obligatory or morally attractive in purely psychologistic terms - which is precisely how Hart should (and perhaps does) understand them - then the practical import of solving the Demarcation Problem changes. What is legally valid is not morally obligatory, and what is morally attractive is not legal obligatory: those are the two key contentions of proponents of the positivist answer to the Demarcation Problem. But this only seems important to emphasize because people actually think the moral is overriding in practical reasoning. In a world in which people, for example, viewed moral obligation as on a par in practical reasoning with would feel pleasant, it is hard to see why the Demarcation Problem would matter. Perhaps legal norms are morally obligatory, but that does not answer the question what should be done. And perhaps certain norms are morally attractive: that does not decide, at all, the question whether a judge should apply them.

Admittedly, the world as the moral philosophers imagine it is one in which morality is overriding in practical reason. We may bracket, for the moment, Nietzschean and Thucydiean skepticism about whether this is the real world. The point that bears emphasizing is that the solution to the Demarcation Problem is supposed to answer a practical question about what ought to be done, one that is reducible to a psycho-social question about the attitudes people have about morality and legality. Thus we may ask

\footnotetext{
${ }^{12}$ See my “Moral Fact and Best Explanations," reprinted in Naturalizing Jurisprudence.
} 
whether there is any reason to think a theoretical solution to the Demarcation Problem will affect the actual psychological attitudes of persons?

Defenders of legal positivism, the dominant answer to the Demarcation Problem in the last two hundred years, are surely familiar with the contention that a solution to the Demarcation Problem has far-reaching consequences for practice. This was, after all, the central thought behind Lon Fuller's famous 1957 attack on H.L.A. Hart, ${ }^{13}$ which has been a target of philosophical derision ever since for its odd mischaracterizations of the claims of legal positivists, including Hart. Fuller thought, simply put, that the blame for the moral depravity of Nazi judges could be laid at the door of their "positivism," i.e., their view that they were bound to apply the legally valid norms of their immoral system (cf. p. 649). According to Fuller, positivism's "definitions of 'what law really is' are not mere images of some datum of experience, but direction posts for the application of human energies" (p. 632) and he reminds us that "words have a powerful effect on human attitudes" (p. 649). Thus, Fuller deems it worth asking "whether legal positivism, as practiced and preached in Germany, had, or could have had, any causal connection with Hitler's ascent to power" (p. 658) and concludes that, due to the ideas of legal positivism, the "German lawyer was therefore peculiarly prepared to accept as 'law' anything that called itself by that name" (p. 659), even, of course, when the law was morally abhorrent.

Fuller's attack has been criticized for its misstatements of Hart's views, such as claiming that Hart believes there is an "amoral datum called law, which has the peculiar quality of creating a moral duty to obey it" (p. 656). That Hart's version of the positivist

13 "Positivism and Fidelity to Law -A Reply to Professor Hart," Harvard Law Review 71 (1957): 630-672. Further citations will be by page number in the body of the text. 
theory of law had none of the implications that Fuller claimed is not the issue. ${ }^{14}$ What requires notice is that the main practical rationale for solving the Demarcation Problem we have identified appears to be the mirror image of Fuller's attack on positivism: namely, that the correct or incorrect view about legality will affect action! To be sure, many legal philosophers might object that their only concern is a theoretical one, namely, figuring out what is true about law. But we have never found any truths about any artifact concepts that would satisfy the desiderata legal philosophers like Raz and Dickson and Shapiro regularly announce, so it is hard to take seriously the idea that there is a theoretical reason for solving the Demarcation Problem. That leaves us, then, only with the practical reasons, and they are real enough, assuming one thinks that confusions about morality and legality have consequences in political practice.

Let us suppose that they do, much as Fuller did. But why, then, think that a jurisprudential solution to the Demarcation Problem would resolve them? That is the key question. If I am right about the practical reason for solving the Demarcation Problem in jurisprudence, then positivism is up against a psycho-social phenomenon: people think that morally obligatory means overriding in practical reasoning, and they think legally valid means morally obligatory. Does anyone seriously believe Kelsen's Pure Theory of Law or Hart's The Concept of Law are the manifestos to counteract these psycho-social phenomena? To think so would be to commit Fuller's mistake, but in reverse. Fuller sought to lay at the door of Hart's positivism the reprehensible behavior of Nazi legal officials. A positivist solution to the Demarcation Problem would, by contrast, teach the Nazis that legal obligations are defeasible, since they are not moral

\footnotetext{
${ }^{14}$ See, e.g., my "The Radicalism of Legal Positivism," Guild Practitioner (forthcoming 2010).
} 
obligations. (Should one really think that Nazi officials would have acknowledged the force of moral norms that would defeat the legal ones?) If Fuller was mistaken, not only in his characterization of positivism but in his claim that it had some "causal connection with Hitler's ascent to power"' (Fuller's words), then why should there be any practical reason to try to solve the Demarcation Problem in jurisprudence?

Law and morality, as we noted at the start, are pervasive normative phenomena in modern societies. We generally believe that judges have a defeasible obligation to apply the law; we also generally believe that judges, like other persons, ought to do what is morally right. These two normative demands can conflict, and then there can be a hard practical questions to answer. The idea that a putative solution to the Demarcation Problem gives us the answer-which seems to be what Fullerians and anti-Fullerians think-is an illusion.

Even though we can not demarcate science and non-science, we still need to assign degrees of epistemic credence to differing claims about what the world is like. And even if we can not precisely demarcate law and morals, we still need to decide what it is we ought to do, and what it is we have an obligation to do. Solutions to Demarcation Problems, if they worked, would give us shortcuts. But if they do not work, then we have to tackle the practical questions directly. In philosophy of science, that has meant concentrated attention on the epistemology of the various sciences, from physics to biology to psychology, and whether their distinctive claims are well-supported by the available evidence. In philosophy of law that would mean focusing on particular legal systems and the practical demands they make upon officials. To take a very American example, the question is not whether the original public meaning of the Constitution is 
the criterion of legal validity in the U.S. legal system — as, for example, the far right Supreme Court Justice Antonin Scalia believes - the question is whether applying the original public meaning in resolving concrete controversies could be morally justified. Even if Justice Scalia were right about the legal meaning of the Constitution, the right conclusion might be that the legal meaning should be discounted.

Some might wonder whether this posture has brought me surprisingly close to the position of Ronald Dworkin in his recent work. ${ }^{15}$ For has not Dworkin chastised legal positivists for attempting to divorce legal philosophy from political philosophy, to divorce questions about what the law is from questions about what it ought to be, and what judges out to do? Indeed, he has, but for reasons wholly unrelated to the considerations adduced here. Dworkin thinks that solving the Demarcation Problem leads to answers to the practical questions, that the two kinds of questions stand and fall together. Thus, Dworkin claims that the positivist solution to the Demarcation Problem entails claims about how judges should decide cases--though as I, and others have noted, this reading involves such a wild fabrication of the positivist position that Fuller looks like an exemplar of interpretive charity by comparison. ${ }^{16}$ For positivists, the fact that a norm is legally valid certainly creates a prima facie legal reason to decide in accordance with the legal norm, but one that is defeasible by other equitable considerations. And, conversely, Dworkin thinks his own theory of law as integrity both solves (or should we say, "dissolves") the Demarcation Problem and tells judges how to decide concrete cases.

\footnotetext{
${ }^{15}$ See, e.g., "Hart's 'Postscript" and "Thirty Years On” in Justice in Robes.

${ }^{16}$ See my "The End of Empire: Dworkin and Jurisprudence in the $21^{\text {st }}$ Century," Rutgers Law Juornal _ (2006), esp. p. _..
} 
The skeptical argument developed here is different. It suggests we abandon the Demarcation Problem in favor of arguing about what ought to be done, whether by judges confronted with novel cases, or citizens confronted with morally objectionable laws, on the grounds that human artifacts never admit of successful analysis in terms of their essential characteristics - the lesson to be learned from twentieth-century philosophy, especially philosophy of science. The lesson, frankly, seems well-confirmed by the increasingly baroque attempts by legal positivists to solve the Demarcation Problem after the valiant and seminal efforts of Kelsen, Hart, and Raz. And it seems equally well-confirmed by the efforts of natural law theorists like John Finnis and Mark Murphy, who really want theorists to focus on morally good law or practically reasonable legal systems, but who insist on claiming that their transparent change of the subject is really an answer to the Demarcation Problem, really a case of saying what "non-defective" law is or what the "focal" cases of law are. ${ }^{17}$ The professionalization of philosophy, including legal philosophy, guarantees, I fear, continued attention to the Demarcation Problem, since specialization always run the risk of generating both an audience and performers for ultimately pointless disputes. In the spirit of Marx's $2^{\text {nd }}$ Thesis on Feuerbach, let me suggest that a "dispute...that is isolated from practice is a purely scholastic question." I can see why Kelsen, Hart, and Raz might have thought that a solution to the Demarcation Problem was both possible and might be relevant to practice. I think we no longer have an excuse for believing this today.

\footnotetext{
${ }^{17}$ [cites]
} 